\title{
A Conceptual Framework for Managing Design Changes in Building Construction
}

\author{
Jeffrey Boon Hui Yap ${ }^{1,2, a}$, Hamzah Abdul-Rahman ${ }^{2}$ and Chen Wang ${ }^{3}$ \\ ${ }^{1}$ Department of Surveying, Lee Kong Chian Faculty of Engineering and Science, Universiti Tunku Abdul Rahman, 43000 Kajang, Malaysia \\ ${ }^{2}$ Faculty of Science, Technology, Engineering and Mathematics, International University of Malaya-Wales, 50480 Kuala Lumpur, Malaysia \\ ${ }^{3}$ Faculty of Built Environment, University of Malaya, 50480 Kuala Lumpur, Malaysia
}

\begin{abstract}
Design changes have always been an innate feature of the construction industry. Despite the various project management techniques, many building construction projects still fail to achieve their time and cost objectives. This paper aims to focus on design changes as a major cause of time delays and cost overruns. It seeks to discuss the causing factors of design changes in building construction projects and highlighting the resulting rework that is detrimental to project performance. Hence, this paper also aims to present a conceptual framework which was developed to better manage design changes through clued-up management decision to avoid future claims and disputes. Recent and current literature is examined and reviewed. The review approach was based on related literature to identified themes. The existing literature is summarised into five discrete themes of "design changes", "rework", "time and cost overruns", "communication" and "decision-making". The synthesised literature is subsequently utilised in the development of conceptual map which provided the direction for designing the conceptual framework. Extensive review of preceding studies on causes of time and cost overruns reveals that design changes is identified as one of the significant factors. However, there are limited studies in this domain. The discussion presents a knowledge gap of linking design changes and rework with decision-making in project management. This finding suggests the need for further empirical study. The framework stresses the importance of communication and management decision as the control mechanism. Researchers and practitioners in construction management field will find this study useful in understanding the causing factors of design changes and its detrimental impacts to project performance which risk the project to claims and disputes. The conceptual framework presents an imperative outcome to encourage further research in developing conceptual causal model of design changes which shows the key causal variables and their feedback loops.
\end{abstract}

\section{Introduction}

Design changes have been seen as synonymous with the construction industry. Frequent changes have often caused time delays and cost overruns [1]. These changes over and over again lead to rework [2] which can degrade the project performance [3]. Without proper change management strategy [4], undesired design changes will result in unexpected rework which lead to delays and disruptions [5]. Delays and disruptions have negative effects on construction project performance [6], [7]. In this paper, the authors emphasize on time delays and cost overruns in building construction project. Deviation of project objectives results in claims and disputes among the contracting parties in the construction project [8]. One of the many cases of design changes that much affected the project performance in Malaysia is the construction of low-cost air terminal Kuala Lumpur International Airport 2 (KLIA2) where cost overruns and time delays are pertinent. The new design concept caused construction cost to increase from the initial RM 1.7 billion to RM 4 billion [9], [10] along with the opening date moved several times. Hence, amplify the need to manage design changes [11] in construction project. The purpose of this study is to develop a conceptual framework for the management of design changes in building construction projects. This study is able to assist researchers and practitioners in gaining an in-depth understanding of the causes of design changes and the relationship of decisionmaking with design changes caused rework as a change management strategy.

\section{Design changes in building construction}

The building construction industry continues to be beleaguered with time delays and cost overruns [12]. Design changes are the top inhibiting factor of time and cost control in construction projects [4]. Therefore, design changes will manifestly cause time delays and cost

\footnotetext{
${ }^{\mathrm{a}}$ Corresponding author: bhyap@utar.edu.my
} 
overruns in construction projects [13]-[20]. Mohamad et al. [21] reported that design changes is a common phenomenon in building construction project which will inevitably lead to claims and disputes. Burati et al. [22] defined design changes as "design deviations which are related to the design of the project that occur when changes are made in the project design and requirements". These changes are any additions, omissions or adjustments made to the original scope of work after a contract is awarded [23] that lead to adjustment to the contract price or contract time [24]. Hence, making construction projects dynamic and unstable [25]. Design changes definition in this paper is synthesized as "regular additions, omissions and adjustments to both design and construction of work in a building construction project that occurs after the award of contract which affects the contract provisions and work conditions that make building construction dynamic and unstable".

Olawale and Sun [4] revealed that construction projects globally share some key characteristics. This is further supported by Abdul-Rahman et al. [11] in the synthesis of preceeding studies where design changes have been named as the critical factor for project delays and cost overuns in construction project at different parts of the world. Even so, studies on project delays and cost overruns in Malaysian context have fall short of identifying design changes as one of the important factors that inhibit project performance (see [26], [27]). The issue of managing design changes has not received much attention in literature [28]. In addition, empirical studies on the causes of schedule and cost escalations due to design changes are limited [15]. This observation provides the underlying motivation for future studies to fill the gap in knowledge in this domain.

\section{Rework in construction}

Rework is a proverbial occurrence in building construction projects. Rework is identified as significant factor for poor project performance [29]. A number of researchers have developed definitions for rework that can be found in construction management literature. According to Love and Edwards [30] and Love et al. [31], rework is defined as "the unnecessary effort of redoing a process or activity that was incorrectly implemented at the first time". Ashford (1992, as cited in [29]) defines rework as "the process by which an item is made to conform to the original requirement by completion or correction". Refering to Hwang et al. [32], rework can be defined as "having to redo work to nonconformance with requirements". Fayek et al. [33] define rework as "activities in the field that have to be done more than once in the field, or activities which remove work previously installed as part of the project regardless of source, where no change order has been issued and no change of scope has been identified by the owner. Even though the definitions and interpretation of rework vary, one common theme prevail - rework refers to having to redo work due to nonconformance to requirments. Literature is replete with studies indicating that significant rework in construction is due to design changes [34]-[36].

\section{Methodology for development of conceptual framework}

The identified themes, issues and gap in knowledge are used to inform the development of a conceptual model for managing design changes in building construction projects. A conceptual framework in the sense being used here can be thought of as a diagram or map of a researcher's current view of the territory being investigated (Miles \& Huberman, 1984, p. 33 as cited in [37]. Figure 1 illustrates the methodology adopted in design and development of conceptual framework which was adapted from Bhattacharya et al. [38]. This is useful for setting the boundaries and limitations of the study which form the basis for the research design strategy and suggest the direction for fieldwork. The first step of design was to identify the knowledge gaps within the research domain through critical appraisal of literature so that the themes and subthemes of the study could be formed. This phase is central for establishment of scope of study. Subsequently, the conceptual framework was developed based on the information synthesized from the literature. The method employed for developing the conceptual framework was carried out in two stages. The first stage was to develop a conceptual framework of causing factors influencing design changes while the second stage is to expand the framework to include rework, decision-making and communication parameters. The conceptual model was then verified internally by revisiting the parameters of study and confirming whether the developed framework is representing the objectives of the study.

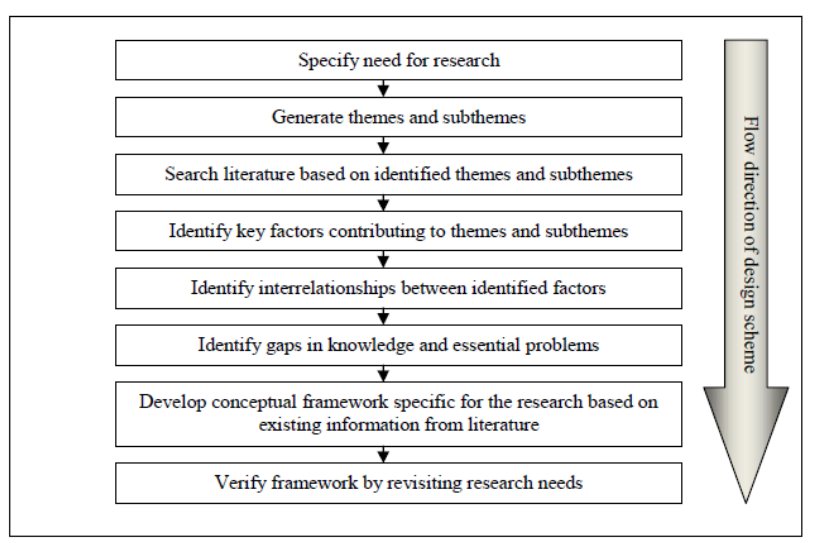

Figure 1. Flow chart showing steps for designing conceptual model (Source: Adapted from Bhattacharya et al. [38])

\section{Causing factors of design changes in building construction}

The focus of this section is the causing factors of design changes, because a good understanding of causes are a prerequisite for understanding the dynamics of design changes in building construction projects. Sun and Meng 
[1] conducted a literature review that synthesizing on project change causes and effects so as to develop taxonomy for change causes and change effects in construction projects. A study by Love et al. [2] indicated that project changes may arise due to the influences of both internal and external elements. Similarly, Alaghbari et al. [27] highlighted that the causes for delay in construction projects are external causes and internal causes. Love et al. [2] described how changes and their actions or effects which are known as dynamics can impact the project management systems. The dynamics can be classified into internal and external factors which are adapted in this paper. On the other hand, Mohamad et al. [21] categorized the sources of design changes from clients, consultants and contractors whom are the primary parties in building construction projects. In this paper, internal factors includes (1) client-related; (2) designrelated; (3) project-related and (4) contractor-related. Figure 2 exhibits the conceptual framework for causing factors influencing design changes.

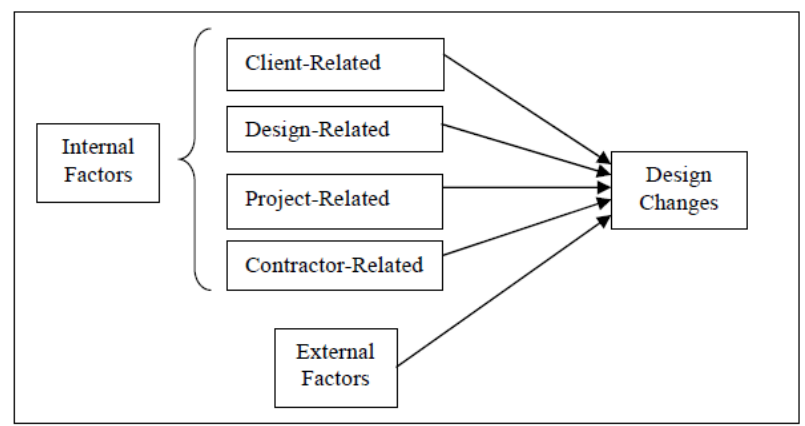

Figure 2. Conceptual framework of causing factors influencing design changes (Source: Adapted from Alaghbari et al. [1], Love et al. [21], Mohamad et al [27], Sun \& Meng [29])

\section{Classification of causing factors of design changes}

A plethora of studies have been done by past researchers to investigate the root causes and nature of changes in construction projects. However, the works on causing factors of design changes are not that prevalent. The following section reviews on the existing literatures that focus on the causes of design changes in construction projects. The literature is further synthesized to design cause-and-effect diagram for design changes that is depicted in Figure 3. Table 1 presents the summary of the sources from existing literature on the identified causing factors of design changes.
Table 1. Identified causing factors of design changes.

\begin{tabular}{|l|l|}
\hline Causing factors & Sources \\
\hline A. Internal Factors & \\
\hline i. $\quad$ Client-related & $[17],[19],[21],[39]-[46])$ \\
\hline ii. Design-related & $\begin{array}{l}{[1],[14],[15],[17],[19],[21],[27],} \\
{[41],[42],[44],[47]-[54]}\end{array}$ \\
\hline iii. Project-related & {$[2],[21],[26],[55],[56]$} \\
\hline iv. Contractor-related & {$[1],[21],[27],[44],[50]$} \\
\hline B. External Factors & \\
\hline i. $\quad$ External-related & {$[1],[2],[15],[26],[27],[44],[55]$,} \\
& {$[57]-[59]$} \\
\hline
\end{tabular}

\subsection{Client-related causes}

Hwang et al. [45] define "client-related rework as the rework that directly originated from client and client's representatives. The study reported that "replacement of materials by the client" was the cause with the highest frequency of occurrence while "change of plans or scope by the client" contributed the most to client-related rework. Similarly, Josephson et al. [42] note the contributing factors of client to rework in Swedish construction industry are client's changes, extra orders, bad choice of material/method and wrong information. According to a study by Mohamad et al. [21], clients are recognised as a major source of design changes. The three major causes of design changes attributed to the clients were modifications to the original design, addition of new work/scope and unclear initial design brief. Some other significant causes comprise of desire to use better specification, desire to use alternative material/new technology and omission of works/scopes. Similarly, a technical report by Federal Construction Council [39] revealed the client's representative as the most significant source of excessive changes in construction. This is further supported by Alnuaimi et al. [40] in a study on public construction projects in Oman where client's additional works is identified as the topmost factor causing changer orders. Again, Ijaola and Iyagba [41] also reported identical findings in both Nigeria and Oman. Another study by Al-Momani [19] reported that the main causes of delay in construction of public projects in Jordan are related to user changes. El-Razek et al. [43] also have almost similar findings in Egypt, Ogunlana et al. [17] in Thailand and $\mathrm{Wu}$ et al. [44] in Taiwan. According to Hwang et al. [45], client-related factors are (1) change of plans or scope by the client; (2) inadequate/incomprehensive project objectives by the client change in specification by the client; (3) financial problems faced by client; (4) impediment in prompting the decision making by the client; (5) replacement of materials by the client; (6) change in specification by the client; and (7) obstinate nature of the client. The data was collected from 381 projects performed by 51 companies in Singapore. Numerous studies show that client-related changes have a significant impact on the project performance. Therefore, client values are important and should be fully understood at the early phase of the project [46]. 


\subsection{Design-related causes}

According to Mendelsohn [47], almost $75 \%$ of problems or rework on construction project were induced at the design phase. The lack of communication between client and design team members can lead to documentation errors and omissions [60]. The design and delivery team often misinterpret the client's requirements in the project [48], [61]. Therefore, Love et al. [60] suggest the communication and harmonious relationship between clients and their design team and the involvement of clients in the design process can appreciably cut designrelated rework. Key designer-related factors include natural growth of the project was not anticipated at the design stage, design errors as well as design and construction criteria are outdated and do not suit the present construction technology [19]. Modification to design was indicated as the second most important causes of change order in both Nigeria and Oman [41]. According to Sun and Meng [1], design consultant generated changes include poor/incomplete drawings, design changes due to poor brief, errors and omissions and inconsistent site condition. Mohamad et al. [21] reported improper design/ part of design improvement, inconsistent information in drawings, discrepancy between contracts, lack of geotechnical investigation/ wrong interpretation of findings and insufficient detail of existing site condition as the factors that caused design changes in residential reinforced concrete buildings. Another study by Cox et al. [49] look into post contract award design changes in construction. Frequent reasons cited are: (1) designer's omission in tender documents; (2) coordination defects in tender documents; (3) employer has changed his requirements; and (4) new information on site conditions. Josephson et al. [42] note the contributing factors of design to rework in Swedish construction industry are lack of co-ordination, unsuitable design, faulty design and incomplete drawings. Kaming et al. [14] describe the magnitude of design changes depend upon pre-design site investigation, the completeness of working drawings available at the time of proposal and unpredictable circumstances during construction. Consultant's inability [55], design omission [15], [27], incomplete drawings [17], design errors [51] and quality of design [44] caused cost and schedule increases. Design changes constitute a major cause of failure in coordination of design information [28]. Defective design is commonly caused by human errors [62]. Design errors can significantly degrade project performance by generating rework, requiring additional time and resource expenditure [52], [53].

\subsection{Project-related causes}

Project specific dynamics include location conditions [2] and underground conditions [21], [26], [55]. The inherent site conditions of a project will affect the project performace [56].

\subsection{Contractor-related causes}

Design changes induce by contractor are due to contractor's request to use available material, to use alternative construction method to save time, to use alternative construction methods to save money, to rectify construction mistakes and to improve the quality of works at site [21]. Similarly, modification of construction methods to suit current site conditions, contractor request for original construction methods to be replaced by a new method as well as improper construction or human-errors leasing to on-site repair work are listed by [44]. Poor planning of project caused errors in execution of tasks and inappropriate construction methods [27], [50]. On the other hand, Sun and Meng [1] included poor site/project management skills, delays in appointing subcontractor, delay of subcontractors' work, poor workmanship, low productivity and poor logistic control as the relevant factors.

\subsection{External-related causes}

Project outcome is most impacted by the regulation imposed by the government [2]. Change of work rules/regulation by the government agencies, neighbourhood communities and coordinating with utility systems as some of the external factors described in Hsieh et al. [55]'s study. In separate study, Sun and Meng [1], Chang et al. [15], Wu et al. [44] and Chang [57] also recognized change orders owing to legislative or policy changes as critical external factor. In Malaysia, the external causes are regulatory changes and problem with neighbours [26]. Alaghbari et al. [27] further expanded the external factors to include materials on the market, equipment and tools on the market, economic conditions, law and regulation and external works due to public agencies (roads, utilities and public services). Aiyetan et al. [58] included physical environmental conditions, economic policy and socio-political conditions as factors in their study. Doloi et al. [59] describe lack of communication with local authorities will influence project performance.

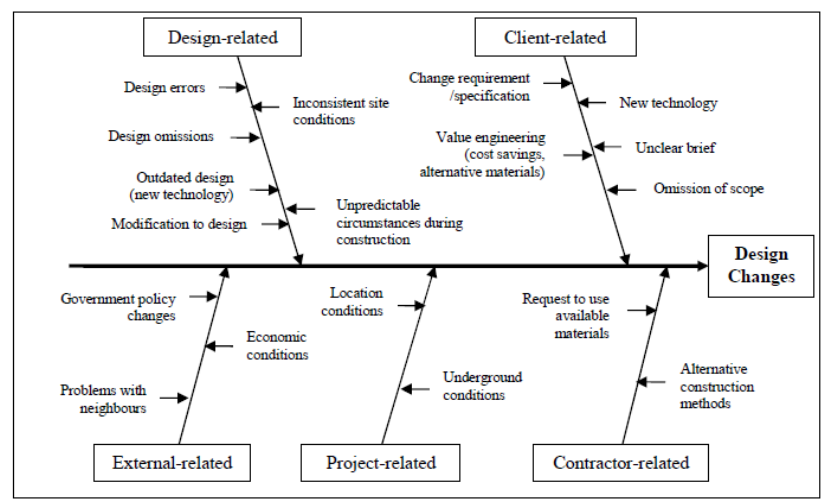

Figure 3. Generic cause-and-effect diagram of design changes (Source: Author derived) 


\section{Impacts to project time and cost performance}

Design changes in building construction projects will inevitably degrade project performance [7], [11], [14], [20], [43], [63]. Although design change has tremendous negative effects [64], attention paid to proactively manage the impact of these changes is limited [65]. There has been considerably research undertaken that has sought to determine the causes of time delays and cost overruns in construction projects [6], [14], [18], [22], [56], [63], [66]-[69]. Research into determining the causes of time delays and cost overruns has reached saturation point; consistently the same causal variables are identified. However, construction projects suffering from overruns are still on the rise. From a recent study in Malaysia, Shehu et al. [70] stressed that distressingly, $55 \%$ of construction projects experienced cost overruns. Abdul-Rahman et al. [71] revealed that practitioners in Malaysian construction industry acknowledge design changes as a major concern to the industry. Chang [15] sampled four project in California and pointed out that schedule and cost increased on average of $69 \%$ and $25 \%$ respectrively as a result of design changes. . Cox et al [49] claimed that the cost associated with design changes were $5-8 \%$ whereas Chang et al. [57] described an average of $8.5 \%$. Love [2] revealed that design change orders resulting in rework can account for as much as $50 \%$ of project cost overrun. Deviation costs averaged $12.4 \%$ of the total installed project cost [22]. These deviations from project objectives are due to disruptions [72] where reworks are required within the construction process [30]. Disruption is fundamental to reduced productivity and increased rework on the project [73]. Hence, disputed and claims over project changes can be minimized when the problems are recognized at the earlier stages of the project [64], especially when client's decision-making is required [74].

\section{Simulation model as decision- support and communication tool}

Changes in construction projects are more often than not unpredictable. This is primarily due to the uniqueness of each project and the limited resources than can be used on planning, executing and delivering the project [75]. By and large, practitioners need to predict changes in a timely manner [76]. Hence, the ability to predict the probabilities of occurrence [71] is essential to mitigate overruns and possible disputes due to design changes and rework [11]. Computer-generated performance simulations are useful to better understand the dynamics of change [77] where critical decision-making can be enhanced through use of predictive models [78]. According to Kartam [76], conflict will be minimised when problems are found at the earlier possible stage of a project thereby enabling the implementation of counter measures. Any request for change will generate costly ripple effects which create delays and disruptions [79] that will affects project performance. Additionally, effective management is difficult in a world of high dynamic complexity where decisions may create unanticipated side effects and delayed consequences [80]. A plethora of research have presented on change management model relating to construction management (see [8], [25], [28], [81]-[84]). But few have link the use of change management model as decision-support tool. Simulation models have been successfully tried to assist decision making (see [85]-[89]). Simulation models are useful to predict the performance of project [90] to aid decision making and policy implementation [91]. Thus, simulation model is imperative to support decisionmaking in dynamic project management.

In highly dynamic project environment, communication becomes complex but essential [92]. Naoum [93] emphasized that lack of timely and effective communication, lack of integration, uncertainty, a changing environment and increasing project complexity are the drivers of project change. With a better understanding of which change factors or combination of change factors are most influential in the development of delay and disruption impacts, the construction industry will hopefully be able to better forecast and manage the impacts of design changes. Simulation models can be used as a communication platform [94] with graphical illustration helpful for visualizing and understanding of impacts of design changes on project performance or termed as "management simulator" [95]. Therefore, practitioners can convey the strategies to other team members or stakeholders at ease.

\section{The proposed conceptual framework}

A model for management of design changes in building construction projects by placing emphasis on management decision is proposed (Figure 4). The simulation model can be deployed to provide effective communication platform through predictive model to understand the dynamics of design changes, the knock-on effects due to rework that cause delay and disruption and possible degradation of project time and cost performance. Therefore, practitioners can acclimatize the simulation data from the predictive model for clued-up decision-making at the point of design change request. Hence, the impacts can be envisaged at the early stage in order to minimize the risk of project to potential claims and disputes at the tail end of the project. 


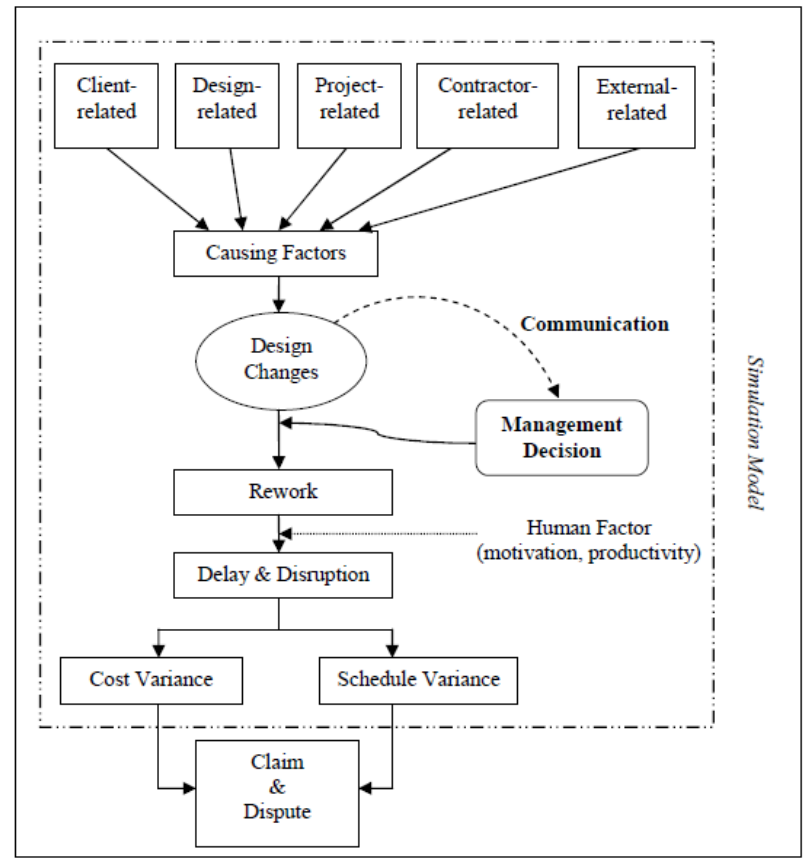

Figure 4. The conceptual framework (Source: Author derived)

\section{System dynamics in managing design changes}

There is now a need for alternative research approaches in construction project management studies [96]. This claim is further justified by Ahiaga-Dagbui et al. [97] that identified methodological gap in current research that lack system thinking and demonstrable causality. By applying system thinking to the problem of design changes by understanding the types of design changes and factors influencing the occurrence of these changes at various times in the project, system thinking can lead the construction industry towards realizing how to prevent or mitigate delay and disruption impacts by anticipating when and where design changes are most likely to occur.

System dynamics (SD) is a methodology for analysing complex systems and problems with the aid of computer simulation software. It is an experimental approach to system thinking [95]. SD modelling has brought a new view to project management, enabling understanding of the behaviour of complex projects that was not accessible with other methods [5]. SD is about studying complex and dynamic systems which change over time, and about finding the "why" (causes) and "how" (pattern) of system changes. According to Sterman [79], [95], SD models are suitable for complex and highly dynamic systems which involve multiple feedback processes with non-linear relationships as well as encompass both "hard" and "soft" data. Human factors such as motivation and productivity are considered as soft variables.

SD models are providing systematic analysis of the strategic issues of project management [98]. SD models have been successfully applied to construction project management [98]-[101]; effect of rework on project performance [2], [52], [102]; change management in construction [65], [103]; decision making in construction [88], [104]; delay and disruptions in construction [5],
[105]; procurement strategies [106], [107]; outsourcing construction services [108] and analyzing project cost overruns [109], among others. SD models can complement the shortcomings of traditional tools and techniques [110]. Besides, significant numbers of researchers promote the use of system dynamics as a solution to improve project decision-making [52], [100], [104], [105]. The information from the SD model can be utilised to aid in making decisions related to design changes where the impacts are often underestimated by construction industry practitioners. The model will enables project manager to address issues by simulating their impacts on the project before they become problems.

\section{Conclusions}

The critical appraisal of literature relating to causes of design changes and the resultant rework that cause delay and disruption which result in time delays and cost overruns in building construction projects has been presented. This study establishes that literature linking design changes and rework in construction projects is limited but found out that design changes is the significant factor for time delays and cost overruns. In order to mitigate the detrimental impacts of design changes, the dynamics that influences design changes need to be identified and attended to appropriately. Researchers and practitioners in construction management field will find this study useful in understanding the causing factors of design changes and its detrimental impacts to project performance which risk the project to claims and disputes. The framework which is a noteworthy outcome from this study stresses the importance of communication and management decision as the control mechanism. Dynamic project management using simulation to building construction projects which is a new trend that assures results by minimizing risks and uncertainties through use of predictive models. It gives the practitioners the ability to view the impacts of design changes to project performance before actually making the decision to implement the proposed design changes. If applied correctly it is able to hoard many projects from disaster. The simulated data can be useful to the critical management decision process. The conceptual map provides a new conceptualization and understanding the interrelationship between simulation, communication and decision-support system. Therefore, this is a unique contribution to the existing body of knowledge. While empirical evidence for this framework is still in an emerging state, the simplicity of the framework put forward broad application in the field of managing design changes as well as time delays and cost overruns research. The conceptual framework presents an imperative outcome to encourage further research in developing conceptual causal model of design changes which shows the key causal variables and their feedback loops. The SD methodology was selected because it can clearly illustrate the dynamics of design changes within the project lifecycle and how the impacts will affect project performance (time and cost). 


\section{References}

[1] M. Sun and X. Meng, "Taxonomy for change causes and effects in construction projects," Int. J. Proj. Manag., vol. 27, no. 6, pp. 560-572 (2009)

[2] P. E. D. Love, G. D. Holt, L. Y. Shen, H. Li, and Z. Irani, "Using systems dynamics to better understand change and rework in construction project management systems," Int. J. Proj. Manag., vol. 20, no. 6, pp. 425-436, (2002)

[3] E. Palaneeswaran, P. E. D. Love, M. M. Kumaraswamy, and T. S. T. Ng, "Causal ascription of rework in building and civil engineering projects: A multivariate exploration," Eng. Constr. Archit. Manag., vol. 21, no. 1, pp. 111-126 (2014)

[4] Y. A. Olawale and M. Sun, "Cost and time control of construction projects: Inhibiting factors and mitigating measures in practice," Constr. Manag. Econ., vol. 28, no. 5, pp. 509-526 (2010)

[5] S. M. Howick, F. Ackermann, C. Eden, and T. M. Williams, "System dynamics and disruption and delay in complex projects," in Encyclopaedia of compexity and system science, Springer (2009)

[6] J. Bin Yang, M. Y. Chu, and H. M. Huang, "An empirical study of schedule delay causes cased on Taiwan's litigation cases," Proj. Manag. J., vol. 44, no. 3, pp. 21-31 (2013)

[7] T. Williams, C. Eden, F. Ackermann, and A. Tait, "The effects of design changes and delays of project costs," J. Oper. Res. Soc., vol. 46, no. 7, pp. 809-818 (1995)

[8] I. a. Motawa, C. J. Anumba, S. Lee, and F. PeñaMora, "An integrated system for change management in construction," Autom. Constr., vol. 16, no. 3, pp. 368-377 (2007)

[9] E. Ng, "No cost overrun for klia2, says Liow," The Edge Markets, 19 May (2015)

[10] R. Ghazali, "Transport Ministry: KLIA2 construction never experienced cost overruns," The Star Online, 19 May (2015)

[11] H. Abdul-Rahman, C. Wang, and J. B. H. Yap, "Impacts of design changes on construction project performance: Insights from a literature review," in 14th Management In Construction Researchs' Association (MiCRA 2015) Annual Conference and General Meeting (2015)

[12] P. E. D. Love, R. Y. . C. Tse, and D. J. Edwards, "Time - cost relationships in Australian building construction projects," J. Constr. Eng. Manag., vol. 131, no. 2, pp. 187-194 (2005)

[13] N. Mansfield, O. Ugwu, and T. Doran, "Causes of delay and cost overruns in Nigerian construction projects," Int. J. Proj. Manag., vol. 12, no. 4, pp. 254-260 (1994)

[14] P. F. Kaming, P. O. Olomolaiye, G. D. Holt, and F. C. Harris, "Factors influencing construction time and cost overruns on high-rise projects in Indonesia," Constr. Manag. Econ., vol. 15, no. 1, pp. 83-94 (1997)

[15] A. S. T. Chang, "Reasons for cost and schedule increase for engineering design projects," J. Manag. Eng., vol. 18, no. 1, pp. 29-36 (2002)

[16] S. Lee, S. R. Thomas, and R. L. Tucker, "The relative impacts of selected practices on project cost and schedule," Constr. Manag. Econ., vol. 23, no. 5, pp. 545-553 (2005)

[17] S. O. Ogunlana, K. Promkuntong, and V. Jearkjirm, "Construction delays in a fast-growing economy: Comparing Thailand with other economies,” Int. J. Proj. Manag., vol. 14, no. 1, pp. 37-45 (1996)

[18] N. . Kartam, T. . Al-Daihani, and J. . Al-Bahar, "Professional project management practices in Kuwait: issues, difficulties and recommendations," Int. J. Proj. Manag., vol. 18, no. 4, pp. 281-296 (2000)

[19] A. H. Al-Momani, "Construction delay: a quantitative analysis," Int. J. Proj. Manag., vol. 18, no. 1, pp. 51-59 (2000)

[20] J. D. Owalabi, L. M. Amusan, C. O. Oloke, O. Olusanya, P. Tunji-Olayeni, OwolabiDele, PeterJoy, and OmuhIganatious, "Causes and effects of delay on project construction delivery time," Int. J. Educ. Res., vol. 2, no. 4, pp. 197 208 (2014)

[21] M. Mohamad, M. Nekooie, and A. Al-Harthy, "Design changes in residential reinforced concrete buildings: The causes, sources, impacts and preventive measures," J. Constr. Dev. Ctries., vol. 17, no. 2, pp. 23-44 (2012)

[22] J. L. Burati, J. J. Farrington, and W. B. Ledbetter, "Causes of Quality Deviations in Design and Construction," Journal of Construction Engineering and Management, vol. 118, no. 1. pp. 34-49 (1992)

[23] A. . Akinsola, K. . Potts, I. Ndekugri, and F. Harris, "Identification and evaluation of factors influencing variations on building projects," Int. J. Proj. Manag., vol. 15, no. 4, pp. 263-267 (1997)

[24] W. Ibbs, "Construction change: Likelihood, severity , and impact on productivity," J. Leg. Aff. Disput. Resolut. Eng. Constr., no. August, pp. 67-73 (2012).

[25] M. Park and F. Peña-Mora, "Dynamic change management for construction: Introducing the change cycle into model-based project management," Syst. Dyn. Rev., vol. 19, no. 3, pp. 213-242 (2003)

[26] M. Sambasivan and S. W. Yau, "Causes and effects of delays in Malaysian construction industry," Int. J. Proj. Manag., vol. 25, no. 5, pp. 517-526 (2007)

[27] W. Alaghbari, M. R. a. Kadir, A. Salim, and Ernawati, "The significant factors causing delay of building construction projects in Malaysia," Eng. Constr. Archit. Manag., vol. 14, no. 2, pp. 192-206 (2007)

[28] A. Mokhtar, C. Bédard, and P. Fazio, "Information model for managing design changes in a collaborative environment," J. Comput. Civ. Eng., vol. 12, no. 2, pp. 82-92 (1998) 
[29] P. E. D. Love, "Influence of project type and procurement method on rework costs in building construction projects," J. Constr. Eng. Manag., vol. 128, no. 1, pp. 18-29 (2002)

[30] P. E. D. Love and D. J. Edwards, "Forensic project management: The underlying causes of rework in construction projects," Civ. Eng. Environ. Syst., vol. 21, no. 3, pp. 207-228 (2004)

[31] P. E. D. Love, D. J. Edwards, H. Watson, and P. Davis, "Rework in civil infrastructure projects: Determination of cost predictors," J. Constr. Eng. Manag., vol. 136, no. 3, pp. 275-282 (2010)

[32] B. Hwang, S. Thomas, C. Haas, and C. Caldas, "Measuring the impact of rework on construction cost performance," J. Constr. Eng. Manag., no. March, pp. 187-198 (2009)

[33] A. R. Fayek, M. Dissanayake, and O. Campero, "Measuring and classifying construction field rework: A pilot study" (2003)

[34] P. E. D. Love, P. Mandal, and H. Li, "Determining the causal structure of rework influences in construction," Constr. Manag. Econ., vol. 17, pp. 505-517 (1999)

[35] P. E. D. Love, P. Mandal, J. Smith, and J. Georgiou, "DECOREM:A design and construction rework minimisation model," in $1 s t$ International Conference on System Thinking in Management, pp. 377-382 (2000)

[36] P. E. D. Love, D. J. Edwards, and Z. Irani, "Forensic project management: An exploratory examination of the causal behavior of designinduced rework," IEEE Trans. Eng. Manag., vol. 55, no. 2, pp. 234-247 (2008)

[37] A. Mitchell, I. Frame, A. Coday, and M. Hoxley, "A conceptual framework of the interface between the design and construction processes," Eng. Constr. Archit. Manag., vol. 18, no. 3, pp. 297-311 (2011)

[38] N. Bhattacharya, J. Lamond, D. Proverbs, and F. Hammond, "Development of conceptual framework for understanding vulnerability of commercial property values towards flooding," Int. J. Disaster Resil. Built Environ., vol. 4, no. 3, pp. 334-351 (2013)

[39] Federal Construction Council, "Managing Changes in the Construction Process.," Consulting Committee on Contract Management, Technical Report, National Academy Press, Washington DC (1983).

[40] A. S. Alnuaimi, R. a. Taha, M. Al Mohsin, and A. S. Al-Harthi, "Causes, effects, benefits, and remedies of change orders on public construction projects in Oman," J. Constr. Eng. Manag., vol. 136, no. 5, pp. 615-622 (2010)

[41] I. a. Ijaola and R. O. Iyagba, "A comparative study of causes of Change orders in public construction project in Nigeria and Oman," J. Emerg. Trends Econ. Manag. Sci., vol. 3, no. 5, pp. 495-501 (2012)

[42] P.-E. Josephson, B. Larsson, and H. Li, "Illustrative Benchmarking Rework and Rework Costs in Swedish Construction Industry," J.
Manag. Eng., vol. 18, no. 2, pp. 76-83 (2002)

[43] M. E. A. El-Razek, H. A. Bassioni, and A. M. Mobarak, "Causes of delay in large building construction projects in Egypt," J. Manag. Eng., vol. 11, no. 2, pp. 45-50 (1995)

[44] C. H. Wu, T. Y. Hsieh, and W. L. Cheng, "Statistical analysis of causes for design change in highway construction on Taiwan," Int. J. Proj. Manag., vol. 23, no. 7, pp. 554-563 (2005)

[45] B. G. Hwang, X. Zhao, and K. J. Goh, "Investigating the client-related rework in building projects: The case of Singapore," Int. J. Proj. Manag., vol. 32, no. 4, pp. 698-708 (2014)

[46] M. H. Thyssen, S. Emmitt, S. Bonke, and A. Kirk-Christoffersen, "Facilitating client value creation in the conceptual design phase of construction projects: A workshop approach," Archit. Eng. Des. Manag., vol. 6, no. 1, pp. 18-30 (2010)

[47] R. Mendelsohn, "The constructibility review process: A constrctor's perspective," J. Manag. Eng., vol. 13, no. 3, pp. 17-19 (1997)

[48] L. Koskela, P. Huovila, and J. Leinonen, "Design management in building construction: from theory to practice," J. Constr. Res., vol. 3, no. 1, p. 1 (2002)

[49] I. D. Cox, J. P. Morris, J. H. Rogerson, and G. E. Jared, "A quantitative study of post contract award design changes in construction," Constr. Manag. Econ., vol. 17, no. 4, pp. 427-439 (1999)

[50] P. González and V. González, "Analysis of causes of delay and time performance in construction projects," J. Constr. Eng. Manag., vol. 140, no. 1, pp. 1-9 (2014)

[51] N. Hamzah, M. A. Khoiry, I. Arshad, W. H. W. Badaruzzaman, and N. M. Tawil, "Identification of the causes of construction delay in Malaysia," World Acad. Sci. Eng. Technol., vol. 72, no. 12, pp. 312-317 (2012)

[52] S. Han, P. Love, and F. Peña-Mora, "A system dynamics model for assessing the impacts of design errors in construction projects," Math. Comput. Model., vol. 57, no. 9-10, pp. 20442053, (2013)

[53] S. Han, S. Lee, and F. Peña-Mora, "Identification and quantification of non-value-adding effort from errors and changes in design and construction projects," J. Constr. Eng. Manag., vol. 138, no. 1, pp. 98-109 (2012)

[54] P. E. D. Love and D. J. Edwards, "Determinants of rework in building construction projects," Eng. Constr. Archit. Manag., vol. 11, no. 4, pp. 259274 (2004)

[55] T. Y. Hsieh, S. T. Lu, and C. H. Wu, "Statistical analysis of causes for change orders in metropolitan public works," Int. J. Proj. Manag., vol. 22, no. 8, pp. 679-686 (2004)

[56] Y. Frimpong, J. Oluwoye, and L. Crawford, "Causes of delay and cost overruns in construction of groundwater projects in a developing countries; Ghana as a case study," Int. J. Proj. Manag., vol. 21, no. 5, pp. 321-326 
(2003)

[57] A. S. T. Chang, J. S. Shih, Y. S. Choo, and Q. 123456, "Reasons and costs for design change during production," J. Eng. Des., vol. 22, no. 4, pp. 275-289 (2011)

[58] A. Aiyetan, J. Smallwood, and W. Shakantu, “A systems thinking approach to eliminate delays on building construction projects in South Africa," Acta Structilia, pp. 19-39 (2011)

[59] H. Doloi, A. Sawhney, K. C. Iyer, and S. Rentala, "Analysing factors affecting delays in Indian construction projects," Int. J. Proj. Manag., vol. 30, no. 4, pp. 479-489 (2012)

[60] P. E. D. Love, Z. Frani, and D. J. Edwards, “A rework reduction model for construction projects," IEEE Trans. Eng. Manag., vol. 51, no. 4, pp. 426-440 (2004)

[61] D. S. Thomson, S. a. Austin, H. Devine-Wright, and G. R. Mills, "Managing value and quality in design,” Build. Res. Inf., vol. 31, no. 5, pp. 334345 (2003)

[62] Andi and T. Minato, "Representing causal mechanism of defective designs: A system approach considering human errors," Constr. Manag. Econ., vol. 21, no. 3, pp. 297-305 (2003)

[63] L. Le-Hoai, Y. D. Lee, and J. Y. Lee, "Delay and cost overruns in Vietnam large construction projects: A comparison with other selected countries," KSCE J. Civ. Eng., vol. 12, no. 6, pp. 367-377 (2008)

[64] C. W. Ibbs, "Quantitative impacts of project change: Size issues," J. Constr. Eng. Manag., vol. 123, no. 3, pp. 308-311 (1997)

[65] K. Cooper and G. Lee, "Managing the Dynamics of Projects and Changes at Fluor," in Proceedings of the International System Dynamics Conference, April, pp. 1-27 (2009)

[66] D. W. M. Chan and M. M. Kumaraswamy, "An evaluation of construction time performance in the building industry," Build. Environ., vol. 31, no. 6, pp. 569-578 (1996)

[67] N. D. Long, S. Ogunlana, T. Quang, and K. C. Lam, "Large construction projects in developing countries: A case study from Vietnam," Int. J. Proj. Manag., vol. 22, no. 7, pp. 553-561 (2004)

[68] G. Sweis, R. Sweis, A. A. Hammad, and A. Shboul, "Delays in construction projects: The case of Jordan," Int. J. Proj. Manag., vol. 26, no. 6, pp. 665-674 (2008)

[69] R. Apolot, H. Alinaitwe, and D. Tindiwensi, “An investigation into the causes of delay and cost overrun in Uganda's public sector construction projects," J. Constr. Dev. Ctries., vol. 18, no. 2, pp. 33-47 (2013)

[70] Z. Shehu, I. R. Endut, A. Akintoye, and G. D. Holt, "Cost overrun in the Malaysian construction industry projects: A deeper insight," Int. J. Proj. Manag., vol. 32, no. 8, pp. 1471-1480 (2014)

[71] H. Abdul-Rahman, M. A. Berawi, A. R. Berawi, O. Mohamed, M. Othman, and I. A. Yahya, "Delay mitigation in the Malaysian construction industry,” J. Constr. Eng. Manag., vol. 132, no. 2, pp. 125-133 (2006)

[72] K. G. Cooper and K. S. Reichelt, "Project changes: Sources, impacts, mitigation, pricing, litigation, and excellence," in The Wiley guide to project technology, supply chain \& procurement management, Vol. 7., P. W. G. Morris and J. K. Pinto, Eds. New York: John Wiley \& Sons, Inc. (2010)

[73] P. E. D. Lover and H. Li, "Quantifying the causes and costs of rework in construction," Constr. Manag. Econ., vol. 28, pp. 479-490 (2000)

[74] C. Koo, T. Hong, C. Hyun, S. H. Park, and J. Seo, "A study on the development of a cost model based on the owner's decision making at the early stages of a construction project," Int. J. Strateg. Prop. Manag., vol. 14, no. 2, pp. 121-137 (2010)

[75] A. S. Hanna, R. Camlic, P. a. Peterson, and M.-J. Lee, "Cumulative Effect of Project Changes for Electrical and Mechanical Construction," J. Constr. Eng. Manag., vol. 130, no. 6, pp. 762 771 (2004)

[76] N. A. Kartam, "Making Effective Use of Construction Lessons Learned in Project Life Cycle," J. Constr. Eng. Manag., vol. 122, no. 1, pp. 14-21 (1996)

[77] A. Arora, "Dynamic project management using simulations," Project Managment Institute (2007)

[78] J. P. Basbagill, F. L. Flager, and M. Lepech, “A multi-objective feedback approach for evaluating sequential conceptual building design decisions," Autom. Constr., vol. 45, pp. 136-150 (2014)

[79] J. Sterman, "System dynamics modeling for project management," Unpubl. manuscript, Cambridge, MA (1992)

[80] J. Sterman, "Learning in and about complex systems," Syst. Dyn. Rev., vol. 10, no. 3, pp. 291-330 (1994)

[81] A. S. Hanna, J. S. Russell, E. V Nordheim, and M. J. Bruggink, "Impact of change orders on labor efficiency for electrical construction," J. Constr. Eng. Manag., no. July/August, pp. 224232 (1999)

[82] W. C. Ibbs, C. K. Wong, and Y. H. Kwak, "Project change management system," J. Manag. Eng., no. July, pp. 159-165 (2001)

[83] I. a. Motawa, C. J. Anumba, and A. ElHamalawi, "A fuzzy system for evaluating the risk of change in construction projects," Adv. Eng. Softw., vol. 37, no. 9, pp. 583-591 (2006)

[84] Z. Y. Zhao, Q. L. Lv, J. Zuo, and G. Zillante, "Prediction System for Change Management in Construction Project," J. Constr. Eng. Manag., vol. 136, no. 6, pp. 659-669 (2010)

[85] K. G. Cooper, "Naval ship production: A claim settled and a framework built," Interfaces (Providence)., vol. 10, no. 6, pp. 20-36 (1980)

[86] H. Doloi and A. Jaafari, "Toward a dynamic simulation model for strategic decision-making in life-cycle project management," Proj. Manag. J., vol. 33, no. 4, pp. 23-38 (2002)

[87] P. Otto, “A system dynamics model as a decision 
aid in evaluating and communicating complex market entry strategies," J. Bus. Res., vol. 61, no. 11, pp. 1173-1181 (2008)

[88] L. C. Bank, M. McCarthy, B. P. Thompson, and C. C. Menassa, "Integrating BIM with system dynamics as a decision-making framework for sustainable building design and operation," in Proceedings of the First International Conference on Sustainable Urbanization (ICSU 2010), 2010, no. December, pp. 15-17 (2010)

[89] Y. Xing, S. Lannon, and M. Eames, "Developing a system dynamics based building performance simulation model-SdSAP to assist retrofitting decision making," in Proceedings of BS2013: 13th Conference of International Building Performance Simulation Association, Chambery, France, August 26-28, pp. 226-233 (2013)

[90] A. S. White, "A control system project development model derived from System Dynamics," Int. J. Proj. Manag., vol. 29, no. 6, pp. 696-705 (2011)

[91] N. P. Repenning, "Selling system dynamics to (other) social scientists," Syst. Dyn. Rev., vol. 19, no. 4, pp. 303-327 (2003)

[92] A. Laufer, A. Shapira, and D. Telem, "Communicating in dynamic conditions: how do on-site construction project managers do it?," J. Manag. Eng., vol. 24, no. 2, pp. 75-86 (2008)

[93] S. G. Naoum, "Critical analysis of time and cost of management and traditional contracts," J. Constr. Eng. Manag., vol. 120, no. 4, pp. 687705 (1994)

[94] R. R. Senescu, G. Aranda-Mena, and J. R. Haymaker, "Relationships between project complexity and communication," J. Manag. Eng., vol. 29, no. 2, pp. 183-197 (2013)

[95] J. D. Sterman, Business dynamics: Systems thinking and modeling for a complex world. Boston: Irwin/McGraw-Hill (2000).

[96] A. Alsehaimi, L. Koskela, and P. Tzortzopoulos, "Need for alternative research approaches in construction management: Case of delay studies," J. Manag. Eng., no. October, pp. 407414 (2013)

[97] D. D. Ahiaga-Dagbui, S. D. Smith, P. E. D. Love, and F. Ackermann, "Spotlight on construction cost overrun research: superficial, replicative and stagnated," in 31st Annual ARCOM Conference, 7-9 September (2015).

[98] A. Rodrigues and J. Bowers, "The role of system dynamics in project management," Int. J. Proj. Manag., vol. 14, no. 4, pp. 213-220 (1996)

[99] C. L. Chang, S. Ogunlana, and K. Saeed, "Construction Project Management: A System Dynamics Approach," in Proceedings of the 1991 System Dynamics Conference, p. 108 (1991).

[100] J. M. Lyneis and D. N. Ford, "System dynamics applied to project management: a survey, assessment, and directions for future research," Syst. Dyn. Rev., vol. 23, no. 2-3, pp. 157-189 (2007)

[101] A. G. Rodrigues and T. M. Williams, "Systems dynamics in project management: assessing the impacts of client behaviour in project performance," J. Oper. Res. Soc., no. 49, pp. 215 (1998)

[102] Y. Li and T. Taylor, "Modelling the impact of design rework on transportation infrastructure construction project performance," J. Eng. Manag., vol. 140, no. 9, p. 04014044 (2014)

[103] S. Lee, F. Peña-Mora, and M. Park, "Webenabled system dynamics model for error and change management on concurrent design and construction projects," J. Comput. Civ. Eng., vol. 20, no. 4, pp. 290-300 (2006)

[104] B. P. Thompson and L. C. Bank, "Use of system dynamics as a decision-making tool in building design and operation," Build. Environ., vol. 45, no. 4, pp. 1006-1015 (2010)

[105] W. Ibbs and M. Liu, "System dynamic modeling of delay and disruption claims," Cost Eng., vol. 47, no. 6, pp. 12-16 (2005)

[106] M. Park, S. Ji, H. Lee, and W. Kim, "Strategies for design-build in Korea using system dynamics modeling," J. Constr. Eng. Manag., vol. 135, no. 11, pp. 1125-1138 (2009)

[107] S. Chritamara, S. O. Ogunlana, and N. L. Bach, "System dynamics modeling of design and build construction projects," Constr. Innov., vol. 2, no. 4, pp. 269-295 (2002)

[108] S. Lisse, "System Dynamics for Outsourcing Construction Services," Int. J. Constr. Eng. Manag., vol. 2, no. 3, pp. 53-61 (2013).

[109] C. Eden, T. Williams, and F. Ackermann, "Analysing project cost overruns: Comparing the 'measured mile'; analysis and system dynamics modelling," Int. J. Proj. Manag., vol. 23, no. 2, pp. 135-139 (2005)

[110] A. Rodrigues, "The role of system dynamics in project management: a comparative analysis with traditional models," in International System Dynamics Conference, pp. 214-225 (1994) 